\title{
The OEAD: New Perspectives on English-Arabic Dictionaries for English-Speaking Users and Users' Surveys
}

\author{
Radia Benzehra (radia@uga.edu) \\ and
}

Don R. McCreary (mccreary@uga.edu) Linguistics Program, University of Georgia, Athens, Georgia, United States of America

The time is now ripe for a revised and enlarged edition of the $\mathrm{OEAD}$, to maintain its position as a fitting partner to Wehr.

Haywood (1991: 3092)

\begin{abstract}
The article sheds light on the necessity of finding new techniques to rank the users' preferences for English-Arabic dictionaries. The first section of the article reports the findings of an experimental technique devised for this particular purpose. The reviews for dictionaries on Amazon.com turn out to be a more valuable source of lexicographical information than had been expected. It will also be shown how the reviews can determine the future buyers' choice as to which English-Arabic or Arabic-English dictionary would meet their needs. Based on the Amazon reviews, the article devotes a section to investigate the microstructural features of some lexical entries in the Oxford English-Arabic Dictionary of Current Usage (OEAD). To learn more about the dictionary's microstructure, the next section analyzes a pre-selected list of 113 lexical units in an attempt to test the dictionary for the amount of information it provides for some high-frequency items. The article deals with the OEAD mostly from the point of view of encoding English-speaking users. The Modern Language Association (MLA) recently reported that from 1998 to 2002 there was a $92 \%$ increase in the number of Arabic programs throughout the United States, hence the pressing need for dictionaries designed with English-speaking users as the target group. The article suggests that an extensive linguistic revision of the OEAD will make it more systematic and userfriendly.
\end{abstract}

Keywords: BILINGUAL DICTIONARY, DECODING USERS, ENCODING USERS, ENGLISH-ARABIC, ENGLISH-SPEAKING USERS, LEARNERS OF ARABIC, LEXICOGRAPHY, MICROSTRUCTURE, REVIEWS, USERS' PREFERENCES

Opsomming: Die OEAD: Nuwe perspektiewe op Engels-Arabiese woordeboeke vir Engelssprekende gebruikers en gebruikersopnames. Hierdie artikel werp lig op die noodsaaklikheid om nuwe tegnieke te kry om gebruikers se voorkeure vir Engels-Arabiese woordeboeke in rangorde te plaas. Die eerste afdeling van die artikel doen verslag van die bevindings van 'n eksperimentele tegniek ontwerp vir hierdie bepaalde doel. Die resensies van woordeboeke op Amazon.com het geblyk 'n meer waardevolle bron van leksikografiese inlig- 
ting te wees as wat verwag is. Daar sal ook getoon word hoe die resensies toekomstige kopers se keuse kan bepaal oor watter Engels-Arabiese of Arabies-Engelse woordeboek aan hul behoeftes sal voldoen. Met die Amazon-resensies as uitgangspunt, wy die artikel ' $n$ afdeling aan die ondersoek van die mikrostrukturele eienskappe van sommige leksikale inskrywings in die Oxford English-Arabic Dictionary of Current Usage (OEAD). Om meer oor die woordeboek se mikrostruktuur te wete te kom, ontleed die volgende afdeling 'n voorafgekose lys van 113 leksikale eenhede in 'n poging om die woordeboek te toets vir die hoeveelheid inligting wat dit verskaf wat betref sommige hoëfrekwensie-items. Die artikel handel meestal oor die OEAD uit die gesigspunt van enkoderende Engelssprekende gebruikers. Die Modern Language Association het onlangs berig dat daar vanaf 1998 tot 2002 'n 92\%-toename in die aantal Arabiese programme dwarsoor die Verenigde State was, vandaar die dringende behoefte aan woordeboeke vir Engelssprekende gebruikers as teikengroep. Die artikel suggereer dat 'n taalkundige hersiening van die OEAD dit meer sistematies en gebruikersvriendelik sal maak.

Sleutelwoorde: TWEETALIGE WOORDEBOEK, DEKODERENDE GEBRUIKERS, ENKODERENDE GEBRUIKERS, ENGELS-ARABIES, ENGELSSPREKENDE GEBRUIKERS, AANLEERDERS VAN ARABIES, LEKSIKOGRAFIE, MIKROSTRUKTUUR, RESENSIES, GEBRUIKERSVOORKEURE

\section{Introduction}

The 1972 edition of the Oxford English-Arabic Dictionary of Current Usage (henceforth OEAD) is the dictionary recommended by teachers of Arabic at the University of Georgia, though they themselves admitted that using the dictionary was not a common practice in their classes. To highlight the underlying features of the OEAD, we examined this 1972 edition which has served Englishspeaking users for 37 years now. Because this edition has never been revised, we examined a few pages from its 1982 abridged version: The Concise Oxford English-Arabic Dictionary of Current Usage (henceforth COEAD). We noted two main differences which indicate that the 1972 edition is more useful for encoding English-speaking users than the abridged edition. The article aims at demonstrating how the OEAD (1972) can constitute a comparable alternative to the other bilingual dictionaries on the market. We do believe that it is time to bring the OEAD up to date with a specific category of users in mind.

The 2002 statistics on enrollments in foreign languages in U.S. institutions of higher education show that "enrollments in Arabic were relatively stable during the 1980s; however, since 1995 they have shown rapid growth, particularly between 1998 and 2002, almost doubling (from 5505 to 10 584)" (Welles 2004: 14). Arabic is among the fifteen most commonly taught languages in the U.S., hence the pressing need for dictionaries designed for English-speaking users as the target group. But what does this category of users think of the different English-Arabic dictionaries available on the market? Which dictionaries do English-speaking learners of Arabic own or use on a regular basis? And what motivates their choice? 
It is important to note that surveys of dictionary users' preferences are still difficult to conduct in a systematic way in American universities. In our university, for example, most learners of Arabic are beginners and are not familiar with English-Arabic dictionaries. They seem to be more absorbed in the intricacies of Arabic grammar than in dictionary use. The reasons behind the nonuse of dictionaries in Arabic classrooms are not within the scope of this article. We are more concerned with finding out alternative techniques that can be used to rank the users' preferences for English-Arabic dictionaries in the United States. Such a ranking would enable us to understand the strengths and weaknesses of English-Arabic dictionaries from actual users' perspectives.

A potentially rewarding perspective on users' preferences is to consult the reviews for dictionaries on Amazon.com, which are numerous. Other websites for booksellers, such as Borders.com and Barnesandnoble.com, have a few reviews, but not as many as Amazon. This might be due to the fact that Amazon.com is one of the most popular websites for booksellers in the US, especially among students. Not only did the customers write reviews for the dictionaries they bought on Amazon, but also future buyers appear to take time and read the reviews posted online when trying to make a decision about buying a dictionary. The readers also leave comments as to whether or not the reviews have been helpful. The reviews take the form of a debate on different aspects of the dictionaries with eye-catching titles such as "Throw your Oxford in the Trash", and replies such as "Don't listen to the idiot who gave one star". The reviews are rated in terms of stars $(5,4,3,2$ or 1 star) and each reviewer justifies the number of stars he assigns to the dictionary.

We should admit that the technique we present in the article still has shortcomings especially from a statistical point of view, as shall be explained later in the discussion, but we do believe that it provides lexicographers with valuable information on what users think of the different bilingual EnglishArabic dictionaries they actually buy and use. The technique is also interesting in the sense that it provided us with a set of criteria along which we evaluated the OEAD from a dictionary user's perspective. In the last section of the article, we examined a pre-selected list of 113 lexical items with the aim of highlighting those areas where the OEAD or any other bilingual English-Arabic dictionary can be improved to - finally - meet the needs of a category of users so far neglected.

\section{Survey of the users' preferences on Amazon.com}

While the editor Doniach (1972) claims that the COEAD contains 35000 words and phrases, he does not suggest any headword count in the front pages of the OEAD. Asfour (2003) obtained his own count of headwords for the dictionaries he analyzed by averaging the headwords in ten randomly selected pages and multiplying the average by the number of pages in the dictionary. We followed the same method and our own count of headwords in the OEAD is 26726 
entries. ${ }^{1}$ The OEAD editor claims in his preface that the dictionary "is designed to meet the needs of those whose mother-tongue is English and who are learning Arabic, and those whose mother-tongue is Arabic and who are learning English" (1972: i). By no means can this ideal be achieved. Haas (1962) suggests that there should be a warning to the potential users that such is not actually the case. One can argue that there are innumerable facts about Arabic which are known to the native speaker, but which are not clear or obvious to the native speaker of English. Thus, a single dictionary cannot adequately help both Arabic speakers of English and English speakers of Arabic. The article focuses mainly on those linguistic areas which are reported by the Amazon reviewers as being problematic.

Considering the customer reviews on Amazon.com, the linguistic areas which seem to pose a problem for the users are mainly phonological and semantic. The users note that the Arabic vowels are sometimes suppressed from the written form in the dictionary. Short vowels in Arabic are indicated by means of diacritics, for example, a short oblique stroke written below the consonant indicates that the consonant is followed by a short / $\mathrm{i}$ / (for more on Arabic diacritics see Schulz 2004). Our analysis indicates a lack of consistency in indicating the Arabic vowels, although one English-Arabic/Arabic-English dictionary by Hippocrene has attempted to solve this problem by using the IPA. What reviewers liked the most about the Hippocrene Arabic Practical Dictionary (2004) is the IPA system adopted in the A-E section. Each Arabic equivalent is transcribed in English; a strategy which facilitates the reading of Arabic words. About this pocket dictionary, one Amazon reviewer writes, "I can quickly find the words and the correct pronunciation. I would recommend it to anyone wanting to learn the Arabic language."

Also most users in the Amazon reviews accuse the two editions of the OEAD of not being accurate because when they use certain equivalents offered by both dictionaries, native speakers of Arabic tell them that they never use such words as can be illustrated from the following quote: "I often found natives saying "we never use this" when I would ask them about translations found in the [OEAD] dictionary. Very rarely, if ever, are the translations within it correct." The users report they get frustrated when they try to find some translations for entries that are either missing or even worse: when the English word has an entry but has multiple Arabic equivalents, no help is offered about which one would apply in a given context. One Amazon customer complains, "Sometimes there are multiple Arabic words for one English entry [in the OEAD]. I would find myself using the first word only, and then asking native speakers or my teacher if that was the right word." It should be noted, however, that the dictionary has been rated by some users as more English-speakerfriendly compared to other dictionaries. One review says, "True, the OEAD is not for beginners, but for anyone who can read Arabic, it is one of the best English-Arabic dictionaries you'll find." Another customer adds, "This is the only English to Arabic dictionary you'll find that gives you thorough examples 
of usage. There is simply no substitute for the English to Arabic for Arabic students at any level."

About the COEAD (1982), a concise edition of the English-Arabic dictionary, one Amazon reviewer, among others, explains: "sometimes there are multiple Arabic words for one English entry. No help is offered about which one would apply to a given situation ...," which is the same criticism addressed to the OEAD. Let us consider the entry for abandon by way of illustration. The entry provides the COEAD user with five equivalents without any further

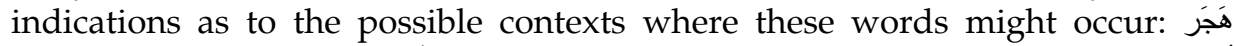

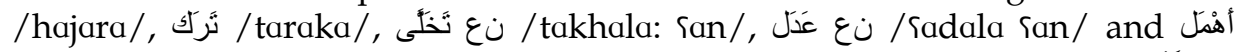

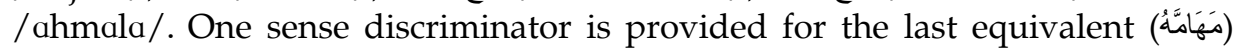
/maha:mahu/ which translates literally as 'duties'. Sense discriminators written in Arabic are not always helpful for English-speaking users. Even in the OEAD, many Arabic equivalents appear in addition to sense discriminators written in Arabic. Such a practice is undoubtedly redundant for Arab users and suits more advanced learners of Arabic.

Another reviewer comments about the COEAD: "you will need a magnifying glass just to attempt to read the script." Indeed, when examining the abridged edition of the OEAD, we noted that the selected typeface is so small that the letters are difficult to read, especially for a new learner of Arabic. We also noted that the editor made some important decisions, such as the addition of the phonetic transcription of the English words, on the one hand, and the omission of many Arabic equivalents, on the other hand. A native speaker of English learning Arabic can dispense with any phonetic information for English; he will rather want more information included in the Arabic side. It might be argued that this information can be helpful for an Arab learner of English, though we do not see why a learner of English would consult a bilingual dictionary to check the pronunciation of an English word. Al-Kasimi (1977: 36) argued: "one can rightly imagine that information about pronunciation is more important for the foreign learner of the language. If he uses his bilingual dictionary to produce the foreign language he certainly wants to know the appropriate word and how to pronounce it."

The need for more information, especially for encoding users, is clearly felt because English and Arabic are so different at all linguistic levels: phonological, morphological, syntactic and cultural above all else. Morphology alone is one of the greatest challenging areas for learners of Arabic. Haywood (1991: 3089) explains that "Arabic has so complex an array of plural forms ('broken plurals') that it is essential for non-Arabs to be given the plurals of a large proportion of nouns and adjectives". Learners of Arabic need to use monolingual Arabic dictionaries which always give plural forms of nouns and adjectives unlike the bilingual dictionaries. Actually, a number of reviewers expressed their satisfaction with the grammatical information the OEAD provides: "not only does it give the past and present verb forms, but it also gives the plural of nouns! One can never hope to learn Arabic without this book." Unfortunately, 
we noted an inconsistency in including plurals in the OEAD. While the dictionary includes the Arabic plurals of pen, book, and nail, the plurals of some other words such as heart, needle, and chair are missing.

The reason for the lack of consistency in the microstructure of bilingual dictionaries has to do with the tendency among editors to ignore the user profile. Atkins and Rundell (2008) argued that a well-defined user profile helps editors make the right decisions about both the macrostructure and microstructure of the dictionary. They put it clearly: "Know your users: that way, the dictionary will give them what they need" (2008: 28). Since this article considers the needs of the English-speaking user of Arabic dictionaries, we will evaluate dictionary treatment from this user's perspective.

The reviews for the OEAD (1972) and the COEAD (1982) refer to several other English-Arabic dictionaries. Many users suggest that Al-Mawrid and Hans Wehr (the editions are not always indicated) and even the Arabic Practical Dictionary by Hippocrene (2004), which is a pocket dictionary, constitute good companions as they include information which is missing in the OEAD. One Amazon reviewer states: "[The OEAD] only includes the English-Arabic dictionary, and you cannot look up Arabic text ... you also cannot look up words by roots", which suggests that some users do not typically favor alphabetic dictionaries, on the one hand, and prefer to have a bi-directional dictionary, on the other hand. We can even read reviews such as "The Hans Wehr Arabic-English Dictionary is probably the best you'll ever get", "If you need an English-Arabic dictionary you can't go wrong with Al-Mawrid" or "The Arabic Practical Dictionary by Hippocrene is much better, though it doesn't show short vowels". 2

Steiner (1984: 167), who quoted Landau's comment on the dictionary reviewers, writes: "reviewers, however well-intentioned, intelligent, and in good command of the use of language, lack a basis for making informed judgments about dictionaries because they do not know why certain decisions were made [in compiling the dictionary]. They do not know what questions should be asked, much less how to answer them." Website reviews should not be totally ignored; they provide lexicographers with valuable information on the market demands. The reviewers of dictionaries on Amazon are 'actual' users who buy dictionaries and seem to know their dictionaries very well. Let us consider the number of Amazon reviews for different editions of English-Arabic/Arabic English dictionaries:

Table 1: Reviews for Hans Wehr Dictionaries

\begin{tabular}{|c|c|c|c|c|c|c|}
\hline Hans Wehr & $\begin{array}{l}\star \\
\star \\
\star \\
\star \\
\star\end{array}$ & $\begin{array}{l}\star \\
\star \\
\star \\
\star \\
\text { औ } \\
\text { is }\end{array}$ & $\begin{array}{l}\star \\
\star \\
\star \\
\star \\
i \\
i\end{array}$ & 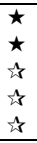 & $\begin{array}{l}\text { औ } \\
\text { is } \\
\text { is } \\
\text { is } \\
\text { is }\end{array}$ & Total \\
\hline $\begin{array}{l}\text { Dictionary of Modern Written Arabic: Arabic-English } \\
\text { (1980) }\end{array}$ & 4 & 0 & 0 & 0 & 1 & 5 \\
\hline $\begin{array}{l}\text { Dictionary of Modern Written Arabic: Arabic-English } \\
\text { Dictionary (1994) }\end{array}$ & 44 & 11 & 2 & 3 & 4 & 64 \\
\hline
\end{tabular}


Table 2: Reviews for Hippocrene Dictionaries

\begin{tabular}{|c|c|c|c|c|c|c|}
\hline Hippocrene & $\begin{array}{l}\star \\
\star \\
\star \\
\star \\
\star\end{array}$ & $\begin{array}{l}\star \\
\star \\
\star \\
\star \\
\star \\
\dot{\nu}\end{array}$ & $\begin{array}{l}\star \\
\star \\
\star \\
\star \\
i \\
i\end{array}$ & $\begin{array}{l}\star \\
\star \\
\text { और } \\
\text { it } \\
\text { is }\end{array}$ & $\begin{array}{l}\text { औ } \\
\text { is } \\
\text { is } \\
\text { is } \\
\text { से }\end{array}$ & Total \\
\hline $\begin{array}{l}\text { Arabic Practical Dictionary: Arabic-English/English- } \\
\text { Arabic (2004) }\end{array}$ & 17 & 7 & 2 & 3 & 3 & 32 \\
\hline $\begin{array}{l}\text { Arabic Compact Dictionary: Arabic-English/English- } \\
\text { Arabic (2004) }\end{array}$ & 0 & 1 & 1 & 0 & 1 & 3 \\
\hline $\begin{array}{l}\text { Hippocrene Standard Dictionary Arabic-English/ } \\
\text { English-Arabic (1995) }\end{array}$ & 0 & 1 & 0 & 1 & 4 & 6 \\
\hline
\end{tabular}

Table 3: Reviews for Al-Mawrid Dictionaries

\begin{tabular}{|c|c|c|c|c|c|c|}
\hline Al-Mawrid & $\begin{array}{l}\star \star \\
\star \\
\star \\
\star \\
\star\end{array}$ & $\begin{array}{l}\star \\
\star \\
\star \\
\star \\
\star \\
i\end{array}$ & $\begin{array}{l}\star \star \\
\star \\
\star \\
\star \\
i \\
i \\
i\end{array}$ & $\begin{array}{l}\text { औ } \\
\star \\
\text { और } \\
\text { मे } \\
\text { मे }\end{array}$ & $\begin{array}{l}\text { 太 } \\
\text { it } \\
\text { it } \\
\text { is } \\
\text { is }\end{array}$ & Total \\
\hline $\begin{array}{l}\text { Al-Mawrid Al-Wasit: English-Arabic and Arabic-English } \\
\text { Dictionary (1985) }\end{array}$ & 2 & 0 & 0 & 0 & 0 & 2 \\
\hline A Modern English-Arabic Dictionary (1997) & 1 & 0 & 0 & 0 & 0 & 1 \\
\hline Al-Mawrid Arabic-English Dictionary (1999) & 11 & 3 & 1 & 0 & 2 & 17 \\
\hline $\begin{array}{l}\text { Al-Mawrid English-Arabic and Arabic-English } \\
\text { Dictionary (2001) }\end{array}$ & 2 & 0 & 0 & 0 & 0 & 2 \\
\hline A Modern English-Arabic Dictionary (2002) & 2 & 0 & 0 & 0 & 0 & 2 \\
\hline A Modern Arabic-English Dictionary (2002) & 5 & 0 & 0 & 0 & 0 & 5 \\
\hline $\begin{array}{l}\text { Al-Mawrid Al Quarib English-Arabic/Arabic-English } \\
\text { Pocket Dictionary (2006) }\end{array}$ & 1 & 1 & 1 & 0 & 1 & 4 \\
\hline
\end{tabular}

Table 4: Reviews for Oxford Dictionaries

\begin{tabular}{|c|c|c|c|c|c|c|}
\hline Oxford & $\begin{array}{l}\star \\
\star \\
\star \\
\star \\
\star\end{array}$ & $\begin{array}{l}\star \\
\star \\
\star \\
\star \\
\text { ᄎ }\end{array}$ & $\begin{array}{l}\star \\
\star \\
\star \\
\text { और } \\
\text { is }\end{array}$ & $\begin{array}{l}\star \\
\star \\
\text { ¿ } \\
\text { it } \\
\text { it }\end{array}$ & $\begin{array}{l}\text { औ } \\
\text { is } \\
\text { is } \\
\text { is } \\
\text { is }\end{array}$ & Total \\
\hline $\begin{array}{l}\text { Oxford English-Arabic Dictionary of Current Usage } \\
\text { (1972) }\end{array}$ & 3 & 1 & 1 & 1 & 1 & 7 \\
\hline $\begin{array}{l}\text { Concise Oxford English-Arabic Dictionary of Current } \\
\text { Usage (1982) }\end{array}$ & 3 & 4 & 3 & 5 & 3 & 18 \\
\hline
\end{tabular}

As the tables show, some dictionaries are more reviewed than others. The Hans Wehr Arabic-English Dictionary (1994) received more reviews than all the other dictionaries. This compact version of the fourth edition (1980) has very positive reviews and is considered to be an essential tool for learning Arabic even by beginners. Users report that a root search in Arabic is more efficient in Hans Wehr than the classical alphabetical search. It is important to mention that the Amazon information for almost all English-Arabic dictionaries states that the customers also bought the Hans Wehr Arabic-English Dictionary (1994) in addi- 
tion to other books on Arabic grammar. The Hippocrene Practical Dictionary (2004), with only 18000 entries, ranks second. This is an indication of how much users prefer dictionaries which do not offer many Arabic equivalents for the English words, in addition to offering the IPA pronunciation of Arabic words in the A-E section. The Al-Mawrid Arabic-English Dictionary (1999) and the COEAD (1982) have almost the same number of reviews, though Al-Mawrid has more five star reviews.

The Al-Mawrid dictionary is probably the most cited dictionary in the literature on Arabic bilingual lexicography. The users consider it to be an authority in the field despite the fact that it lacks examples of usage. Its readibility is lower due to the density in the page layout. Unfortunately we found several mistakes in Amazon.com in relation to the Al-Mawrid dictionaries. First, there is some confusion in the year of publication and the bilingual dictionary's direction (English-Arabic or Arabic-English) of some editions and added to this the fact that the exact same reviews for the Al-Mawrid Arabic-English Dictionary (1999) appear under another edition: Al-Mawrid Al-Quarib English-Arabic/Arabic-English Pocket Dictionary (2005). Such mistakes can mislead the readers who read the reviews to obtain more information on the edition they want to buy.

On the positive side, Amazon.com publishes the sales rankings of all its products, though for competitive reasons it does not publish what an item's actual sales are. The Amazon sales ranking is a good indicator of how well a dictionary is selling overall: the lower the number of the sales ranking, the higher the sales for that particular item. The bilingual dictionaries that have high rankings compared to other dictionaries in the same category are shown on the Amazon page. The table below reveals the ranking of the above-listed Arabic bilingual dictionaries. The ranking includes those dictionaries for which reviews have been written. Note that the sales rankings are updated on a regular basis and these were the results obtained on July 7, 2009.

Table 5: Sales rank of some English-Arabic dictionaries on Amazon.com

\begin{tabular}{|r|l|c|}
\hline & Dictionaries & $\begin{array}{c}\text { Sales rankings in books } \\
\text { (low \# = higher sales) }\end{array}$ \\
\hline 1 & $\begin{array}{l}\text { Hans Wehr Arabic-English Dictionary: The Dictionary } \\
\text { of Modern Written Arabic (1994) }\end{array}$ & $\# 830$ \\
\hline 2 & $\begin{array}{l}\text { Hippocrene Arabic Practical Dictionary: Arabic- } \\
\text { English/English-Arabic (2004) }\end{array}$ & \#14 441 \\
\hline 3 & $\begin{array}{l}\text { Al-Mawrid Al Quarib English-Arabic/Arabic-English } \\
\text { Dictionary (2005) }\end{array}$ & \#89649 \\
\hline 4 & $\begin{array}{l}\text { Hippocrene Standard Dictionary: Arabic-Eng- } \\
\text { lish/English-Arabic (1995) }\end{array}$ & \#151232 \\
\hline 5 & $\begin{array}{l}\text { Concise Oxford English-Arabic Dictionary of Current } \\
\text { Usage (1982) }\end{array}$ & $\begin{array}{l}\text { Hans Wehr Dictionary of Modern Written Arabic } \\
(1980)\end{array}$ \\
\hline
\end{tabular}




\begin{tabular}{|c|c|c|}
\hline 7 & $\begin{array}{l}\text { Oxford English-Arabic Dictionary of Current Usage } \\
\text { (1972) }\end{array}$ & \#308359 \\
\hline 8 & $\begin{array}{l}\text { Al-Mawrid English-Arabic and Arabic-English Dic- } \\
\quad \text { tionary (2001) }\end{array}$ & \#421 668 \\
\hline 9 & $\begin{array}{l}\text { Al-Mawrid Al Quarib English-Arabic/Arabic-English } \\
\text { Dictionary (2006) }\end{array}$ & \#484053 \\
\hline 10 & $\begin{array}{l}\text { Hippocrene Arabic Compact Dictionary: Arabic- } \\
\text { English/English-Arabic (2004) }\end{array}$ & \#561 146 \\
\hline 11 & Al-Mawrid Arabic-English Dictionary (1999) & \#620 744 \\
\hline 12 & A Modern Arabic-English Dictionary (2002) & \#747363 \\
\hline 13 & A Modern English-Arabic Dictionary (2002) & \#1 570915 \\
\hline 14 & $\begin{array}{l}\text { Al-Mawrid Al-Wasit: English-Arabic and Arabic- } \\
\text { English Dictionary (1985) }\end{array}$ & \#1 763291 \\
\hline 15 & A Modern English-Arabic Dictionary (1997) & \#4 425410 \\
\hline
\end{tabular}

Customers' preferences have been placed in rank order from 1 to 15 . We observed the sales rankings for a few days and despite changes in the above numbers the ranking follows the exact same order. The table clearly indicates that Arabic-English and bi-directional dictionaries rank above English-Arabic dictionaries. There is also a preference for compact (less than 1000 pages) and concise dictionaries. These results might be interpreted in different ways; it could be that a model dictionary for Arabic learners is a small bi-directional dictionary in which the Arabic words are arranged according to a root-based entry system and the pronunciation of the entry words (often in IPA) included. The English-Arabic section offers as few equivalents as possible, indicating the parts of speech of the equivalents, and presents them in concrete examples of usage. The font of the 'accented' Arabic words is readable. The reviewers' comments on the poor binding of some editions, the size and the price of the dictionary reflect the users' interest in every aspect of the book, including commercial considerations.

Notice also that the most favorably-reviewed dictionary sells very well. Surprisingly the least bought dictionary is an English-Arabic dictionary. Now whether or not we can assume a correlation between the dictionary sales rank and the number of reviews needs further investigation mainly because we have to add to our counts the number of people who read the reviews and say to what extent the reviews have been helpful. For example, 163 people have read a review for Hans Wehr (1994) alone. The review entitled, "The only essential Arabic dictionary for English speakers", has been chosen as the most favorable one. The readers said the review was very helpful. This might explain the high ranking of this particular dictionary. As for the Oxford dictionaries, 144 people have read the 25 reviews posted online: 56 readers out of 61 find the two star reviews of the Oxford dictionaries helpful while 15 out of 17 readers found the five star reviews helpful. It should be explained that the Amazon reviews are divided into 'the most helpful favorable review' and 'the most helpful critical review'. Two reviews are chosen among all the reviews to represent those two categories. For the Al-Mawrid Arabic-English Dictionary (1999), we can read that 
45 of 45 people found the most favorable review helpful whereas 42 of 43 found the most critical review helpful.

The Amazon reviews reflect, at least to some extent, the actual situation of the English-Arabic dictionary market. However interesting, the technique presents a few challenges for the researcher. The first challenge that faces this technique is that there is no normal sampling procedure in order to do a statistical analysis. The reviewers are sometimes anonymous so we have no information about their backgrounds. Also their level of Arabic is not always selfreported. What we want to emphasize in the present article, however, is that the survey technique based on reviews on Amazon posted by anonymous dictionary users is a resource to be more fully exploited and systematized in the future. The reviewers can be asked to provide some more relevant information, a standard practice when administering questionnaires or conducting interviews. For the purposes of our analysis, we used the Amazon reviews as a point of departure in analyzing some lexical entries in the OEAD. The issue under investigation has to do with the features that can be included in a future edition of the OEAD to make it more user-friendly. As one of the reviewers put it: "Hopefully, Oxford takes the time to update and improve this dictionary."

\section{Criteria for treatment of entries for English-Arabic encoding diction- aries}

In an attempt to find out how helpful this dictionary is to the encoding Englishspeaking users, we evaluated a few lexical entries according to the following criteria:

To what extent does the dictionary provide accurate and complete meanings of entries? Holes (1992) explained that for a lexical entry to be accurate, the listed equivalents should be distinguished and should appear in examples to help someone who is seeking le mot juste when translating or expressing himself in Arabic.

- Are parts of speech distinguished in Arabic? For example, the difference between the noun /sarh/ (edifice) and the verb /sarraha/ (declared) lies in the fact that a noun can be transformed into a verb by geminating the sound /r/ and by adding the vowel / a/ between the /r/ and / $/$ sounds. Gemination is signaled in Arabic by a symbol called 'shadda' above the sound in question [" 3 ], and the short vowel added after the /r/ sound is indicated by a symbol called 'fatha' at the top of the sound [₹]. Derivations are very important to consider in a dictionary since derivation implies a new meaning.

- Are there usage labels which indicate the stylistic suitability of an equivalent? Many TL terms differ from each other in terms of style and register; some equivalents are rather old fashioned whereas others are in current usage, as the title of the dictionary suggests. 
- Are the English cultural expressions transferred into Arabic through a literal translation, a paraphrase, or by functional equivalence? Equivalent idiomatic expressions are crucial to an English learner of Arabic who wants to use such multi-word expressions - effectively - when writing or speaking in Arabic. This is part of acquiring communicative competence in a given language. Arabic abounds with semantically challenging expressions. Does the dictionary provide the users with equivalent expressions of, at least, the most common English idioms? Which translation strategy is adopted?

Accuracy is attested in terms of sense discriminators and examples of usage, the focus being on the latter. Creamer (1987: 238) explains, "Often the information the learner is seeking, such as usage, collocations, and points of grammar, can be effectively and efficiently demonstrated by the inclusion of carefully chosen examples." It follows that the primary purpose of an example is to demonstrate the use of a word in its natural environment. Even when sense discriminators are not opted for, the example can illustrate points of usage; e.g., if the entry collocates with a certain noun indicating the typical modifiers. Examples show clearly and in an economical way the various ways the entry can be translated in context. This is exactly what an English user would expect from his bilingual dictionary: providing translations in context rather than a mere listing of the possible Arabic equivalents which as we argued earlier, suits advanced Arab learners of English who use the dictionary for decoding purposes. Consider the entry for affect in the OEAD in Figure 1.

\section{Figure 1}

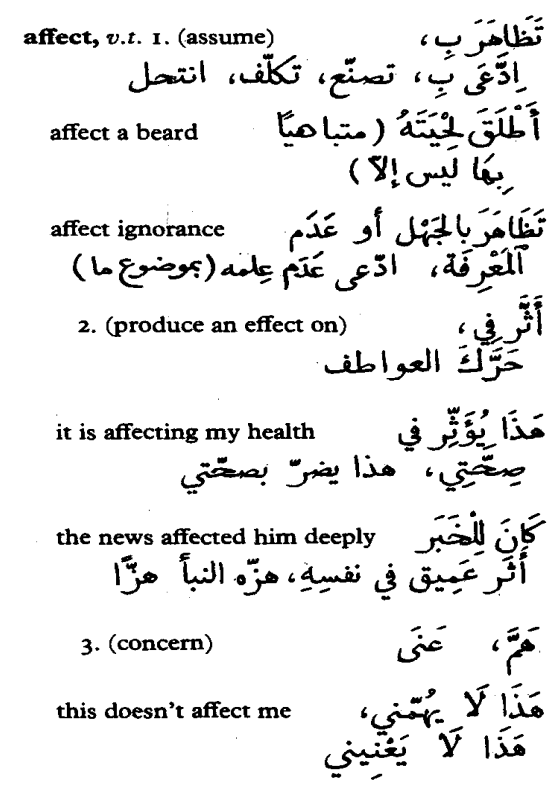


Five equivalents are provided next to each other in the first two lines without further explanation. Moreover, some words are not semantically related to the

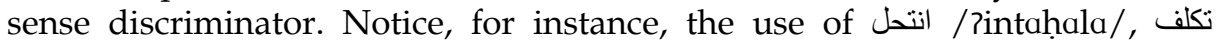
/takallafa/, تصنع /tașṣana\{a/, ادعى ب /Ridda\{a: bi/ and تظاهرب /taḍda:hara bi/ which, according to the editor, correspond to affect when it means assume. All the words are partial synonyms in Arabic which can be possible equivalents of pretend or disguise. The most important comment that can be made has to do with the fact that the least common meaning of affect is presented first instead of its most common meaning 2. Such an order can also mislead learners of English who may consult the dictionary for decoding purposes. We also question the above-mentioned words as being appropriate equivalents at all.

Let us consider another entry in the OEAD:

Figure 2

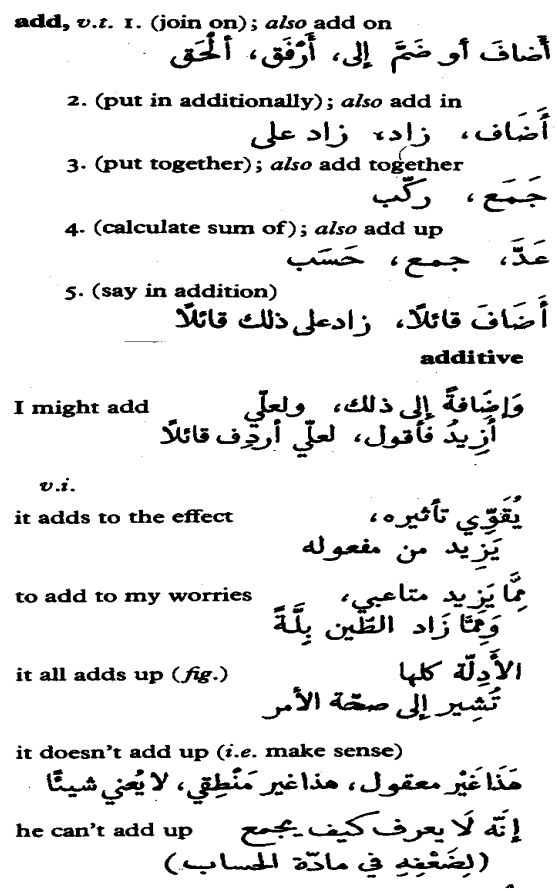

The entry for add specifies that the verb can be transitive and intransitive. Then

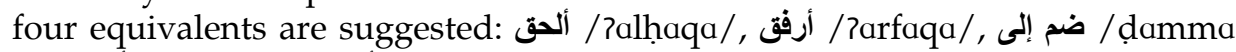
2ila:/ أضاف /aw / ( orada:fa/. The three last equivalents to the left do not appear later when the editor suggests the contexts in which other Arabic equivalents can be used. The verb with which add shares the same core meaning is أضاف /Zada:fa/, whereas the other verbs suggest additional meanings, for example, ضم /damma/ which is rather to include, whereas the two other verbs have specific collocates which the dictionary does not mention. So no more 
information is provided to help the users choose one equivalent. If we want to translate a sentence, such as, Beat the butter and sugar together and slowly add the eggs, only the first equivalent works out; the other words are completely irrelevant.

Under 4 (calculate sum of), three equivalents are presented without fur-

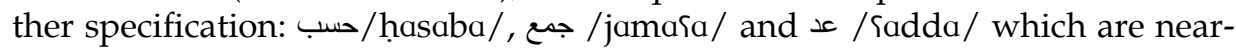
synonyms in Arabic but are not interchangeable. For example, عد/Sadda/ would be rather to count which does not correspond to the sense discriminator at all. It is very important to introduce these verbs in concrete examples. A native speaker of Arabic, of course, would see the nuances in meaning without any problem. An English learner, however, will certainly be confused. The same analysis applies to the entries for adjust, adapt, affect, arrest and arrive. Even when the dictionary provides sense discriminators in English, each sense discriminator corresponds to more than one equivalent, some of which are sometimes completely irrelevant. For example, in the entry for the noun خطبة address, the English-speaking user is not told how to differentiate between /khutba/ and حديث/hadi:th/, which are both polysemous words in Arabic and specific to given contexts.

Another point worth mentioning has to do with the organization of the microstructure of the entry for add itself. We do not understand, for example, the point behind introducing the main equivalent أضاف/Rada:fa/ (add) under separate meanings. The meanings of add which correspond to this same Arabic word should appear all together in addition to examples which illustrate the different morphological forms this verb takes: أضاف/Rada:fa/, ضف/dif/ (imperative) or إضافة إلى ذلك /Rida:fatan 7ila: dha:lika/ (in addition to that). Each form depends on the position of the word in the sentence. Such derivations, which have morphological and syntactic implications, are not really of particular interest to the editor. Unless the dictionary is intended for advanced learners of Arabic, such intricacies are difficult for most students to handle.

We also noted the use of such explanatory sentences for ask someone out, for example:

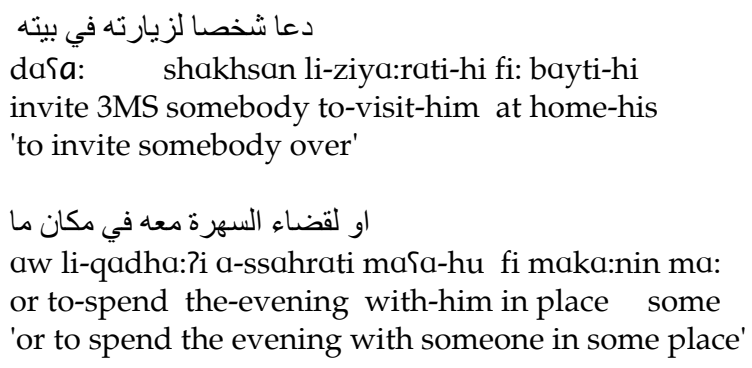

The dictionary does not contain examples of how and where to use such equivalents which are rather explicative. Zgusta (1984: 147) writes, "The dictionary should offer not explanatory paraphrases or definitions, but real lexical units of the target language which, when inserted into the context, produce a 
smooth translation." In other words, the equivalent should be a lexical unit insertable in actual sentences. Functional useable equivalents should also be semantically related to the entry word. The comparison of some entries in the Al-Manar English-Arabic Dictionary (1971) revealed the use of many inappropriate equivalents which would surprise a native speaker of Arabic. Abroad, for example, is rendered as خارج البيت / kha:rija al-bayti/ (outside the house) which is a clear mistranslation. Al-Manar is definitely not helpful for encoding English-speaking users as there are no sense discriminators in English for the Arabic equivalents.

The OEAD should be given credit for the fact that it often provides English sense discriminators for each equivalent, as it does for add. Each sense discriminator is put between brackets to the left of the Arabic equivalent(s): (put together), (calculate the sum of), (say in addition), etc. We noted one sense discriminator in Arabic at the end of the entry in figure 2:

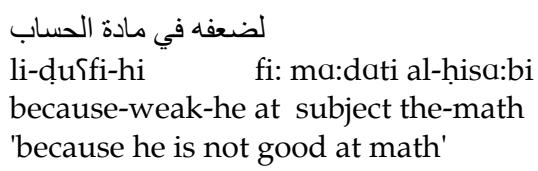

We also liked the practice of translating some expressions into Arabic such as I might add, It adds to the effect, and He can't add up. We thought that the last sentence could serve as a good illustrative example under (calculate sum of) instead of being presented separately. However, when asked about the grammaticality of the sentence He can't add up, native speakers explained that add up is transitive, as in She added the bill up, while It doesn't add up is an idiom, meaning It doesn't make sense (ironically). Lexical mistakes of this kind on both the English and the Arabic sides may now be avoided by employing corpus linguistics in dictionary creation. Arabic bilingual lexicography should develop contacts with spoken and written corpora to discover more contemporary uses of words. Lexicographers should not rely on their knowledge of Arabic because Modern Standard Arabic is nobody's mother tongue. Abu-Ssaydeh (2008) suggests the use of lexical data available through the search engine Google due to the lack of online lexical corpora. Corpus use, procedures for building up corpora and extracting data from them are all areas eagerly awaiting more research in the field of Arabic bilingual lexicography.

A general problem in the OEAD is the inclusion of some verbs as potential equivalents despite the fact that they are subject to a number of syntactic constraints. For example, when we want to translate the sentence If you add three and four you get seven into Arabic, we can use جمع /jamafa/, whereas عد /Sadda/ would be used to translate, for instance, He can count from one to ten. If, on the other hand, we decide to use حسب /hasaba/, we need to add a noun the sum of, i.e., this verb cannot be used by itself. A sentence such as Her colleagues' laughter only added to (= increased) her embarrassment, for example, can be included to illustrate common uses of the entry word. The entry must provide an accurate 
translation, or at least the relevant part of the sentence, such as, add to someone's embarrassment to save space. The entry for add includes two idiomatic expressions accurately translated, in the sense that this is how they are rendered by Arabic speakers: to add to my worries and It all adds up. Other common expressions, such as, to add insult to injury or add fuel to the fire/flames or add salt to the conversation do not appear under add. In fact, when examining other entries, we noticed that some idioms with which we are familiar are absent. The second section of this article tests the dictionary for idiomaticity. During our analysis we did not come across usage labels. The only label used in the entry for add is (fig.) next to It all adds up, which means that more usage labels are needed to provide a better understanding of the information the dictionary includes.

Apart from the fact that many equivalents are provided for each meaning, the pages in the OEAD are not cluttered and it is easy for the users to locate the meaning. Some Amazon reviewers praised the OEAD for the clarity in the page layout: "very clear and legible Arabic typeface". Each sense or example sentence is presented in a separate line. This strategy takes up space and so we suppose that the clarity in presentation is gained at the expense of the amount of information the dictionary provides. We chose some of the most common collocations and fixed expressions to test the dictionary in terms of coverage of the most typical contexts in which some high frequency words appear. We now turn to this next part of the analysis.

\section{The OEAD coverage of high frequency lexical items}

The above analysis suggests that scrutinizing few entries can result in pages of criticism which may "turn out to be an essay on lexicographical matters" (Steiner 1984: 167). It also revealed another problem related to the dictionary's microstructure. We had the impression that the OEAD misses frequent collocations and idiomatic expressions which are associated with some common words. It is true that no bilingual dictionary is expected to include all possible occurrences of the word and its translations. But it should at least include equivalents for the most frequent collocations, syntactic items, and fixed expressions in the users' native language to help them speak correctly or write appropriately in the foreign language. According to Shehdeh and Bin Moussa (2007: 42), "The unavailability of an expression in a dictionary very likely motivates the user to resort to either interpretation, or literal translation, which might be erroneous." Needless to say that collocations and idioms are indispensable for the encoding users who, as we saw in the Amazon reviews, are concerned with sounding natural in the foreign language.

To test the dictionary for coverage we selected a list of 113 lexical items. The list includes high frequency collocations, syntactic items, fixed expressions, and a few colloquial items. These were the lexical/grammatical areas Patzold (1994) tested in addition to some areas of vocabulary coverage in English- 
German learners' dictionaries. Such a method of testing dictionaries for coverage is an attempt at a comprehensive review of dictionaries. We should like to say that our lists are not precisely similar to Patzold's as they sometimes include different lexical and grammatical items.

\subsection{Collocations and fixed expressions}

It can be argued that the absence of collocations from bilingual dictionaries results in the learner's use of unusual and unacceptable combinations of words. Patzold noted that the meaning 'part or piece of something' is realized differently with different nouns in English (1987: 179).

\subsubsection{Noun + of + noun}

(1) Cake: A slab of - (2) Coal: a bag of - (3) Cotton: a wad of - (4) Earth: a clod of (5) Excitement: a twinge of - (6) Glasses: a pair of - (7) Guilt: a pang/ a twinge of - (8) Orange: a segment of - (9) Butter: pat of - (10) Salt: a pinch of - (11) Paper: a sheaf of - (12) Potatoes: a sack of - (13) Rubbish: a load of - (14) Snow: a drift/ flake of - (15) Tea: a pot of - (16) Water: a drink/ trickle/ sip of -

Most of the above combinations were found in the OEAD but not necessarily with the corresponding nouns. For example, the dictionary lists a twinge of conscience or of excitement instead of guilt. Pang only appears with conscience and trickle with information. Flake in (14) is used in corn-flakes and soap-flakes but not with snow. In (15), tea collocates with bag rather than pot, which is also a frequent collocation in English. Overall, we see that the dictionary generally covers such specific combinations. It also helpfully suggests other possible collocates.

\subsubsection{A set of different collocational patterns}

We chose some combinations from Patzold's list below (1994: 40):

(17) Amuse oneself thoroughly (18) Apologize profusely (19) Ask pointedly (20) Fall asleep (21) Mount an attack (22) Well aware (23) Wheel one's bicycle (24) Bleed freely (25) Blush furiously (26) Bored stiff (27) Cooked breakfast (28) Catch one's breath (29) The fog cleared (30) Stark contrast (31) Plodding conversation (32) Mad keen (33) Debate hotly (34) Load the dishwasher (35) Doze fitfully (36) Drink deeply (37) Call an election (38) Arouse expectations (39) Start a family (40) Heavy fine (41) Guard jealously (42) Hint darkly (43) Ignore studiously (44) Conduct an interview (45) Boil a kettle (46) Break the news

The analysis of the above expressions in the OEAD drew our attention to the problem encountered when translating certain grammatical classes into Arabic, such as adverbs. In fact, we can even assume that this part of speech is almost absent in the dictionary, as if Arabic has no adverbs. In his preface, the editor 
explains that "Adverbs in '-ly' and abstract nouns in '-ness', formed from adjectives, are normally omitted unless either their formation is irregular or their usage is more frequent than or in some way different from the adjective from which they derive, e.g., 'actually'; 'muchness' [sic]" (1972: viii). The scarcity of Arabic sentences with adverbs and the absence of adverbs as possible entry words in the OEAD is a problem for encoding users.

There are a few examples where the editor of the OEAD presents equivalents for such constructions as verb + adverb, for example, profusely in (2) appears under profuse in apologizing profusely for being late. Pointedly in (3) is missing in either entry (ask and pointed), instead there is one example: $a$ pointed remark. An Arabic equivalent adverb cannot possibly be derived from the adjective لاذعة /la:dhi§a/ (a feminine adjective, as the equivalent of remark is feminine in Arabic). Hence, the dictionary rarely illustrates such constructions as verb + adverb as in (17), (18), (19), (24), (25), (35), (36), (41), (42) and (43). Notice that debate hotly is rendered as جادل/ja:dala/, a verb which includes two components as part of its meaning (debate + hotly). For example, the collocation in (20) is found in the dictionary but, as illustrated earlier in the article, three equivalents are suggested without any specification as to where to choose one or the other.

We also noted that though the dictionary does not necessarily include the above-mentioned collocations, it is a rich source of many other collocational combinations. The latter, when not presented separately, can be located in the example sentences. Two or more pages are sometimes devoted to one entry word, though some proposed equivalents appear to be uninformed by English native speakers' input which explains the Amazon reviewers' complaints reported earlier in the article.

The inclusion of more collocators would help the user choose one equivalent among the listed equivalents as in the fog cleared (29). The dictionary does not specify that انجلى /Rinjala: /, which is one possible equivalent of clear, in fact, co-occurs with fog. In (38), arouse co-occurs with interest and does not appear under the entry for expectation. This would lead the learners of Arabic to adopt different strategies when asked to translate arouse expectations (38). They will probably look up arouse and expectations separately, then combine both equivalents; a strategy which does not work out all the time. We cannot look up boil and kettle in (45), then combine their equivalents since in Arabic a kettle cannot be boiled. More research on the users' strategies will reveal the way users deal with this problem and whether their strategies are successful or not.

Other inconsistencies have been identified when looking up the above expressions. One observation has to do with the presentation of labels; the latter are sometimes placed between two lists of equivalents so that we do not know where the label belongs. Of course, this would not pose a problem for native speakers of Arabic, but this would only add to the confusion of the English-speaking users. Surprisingly, cook in (27) is assigned an equivalent which is then conjugated in the present tense. Moreover, two alternate pronuncia- 


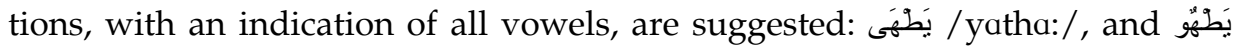
/yathu:/.

There is also another editorial decision which seems to apply to some words and not to others. It has to do with the inclusion of some colloquial equivalents as for bicycle in (23) for which عجلة / عajala/ (wheel) is suggested. When looking up other entries in the OEAD, we noticed that the editor suggests some words from the dialects spoken in the Gulf or in Egypt without any indication of the dialectal variety. If colloquialisms are admitted in the dictionary there should be specific labels for them. It is our belief, however, that there is a serious need for more bilingual dictionaries in which 'current' Modern Standard Arabic is represented. A third set of phrasal verbs from Patzold will be analyzed in what follows (1987: 179).

\subsubsection{Phrasal verbs + collocations:}

(47) Blow up a bridge (48) Call off a strike (49) The flower has come out (50) Come up with an explanation (51) Drive out doubts (52) Enter into the spirit of something (53) Flag down a taxi (54) Gloss over a difficulty (55) Go up to university (56) Hand down an heirloom (57) Her career took off (58) Live down the past (59) Pick out a tune (60) Piece together a story (61) Set off a challenge (62) Stave off hunger (63) Talk round a subject (64) Work out a plan

The analysis of the OEAD treatment of these collocations corroborates the findings in the previous discussion. The above collocations are more specific than the combinations in the previous set due to the addition of an element (often called a particle), either a preposition or an adverb. In fact, most phrasal verbs appear in the OEAD, but not always with the above-listed collocators. The entry for go in (55) has three full pages which display the different meanings of the verb, in addition to a list of sense discriminators in English next to the Arabic equivalents.

The only problem is that the number of equivalents which correspond to only one sense discriminator makes the choice very difficult for the encoding user. Come out in (49) has five Arabic equivalents presented all on the same line separated only with a comma. In fact, each equivalent co-occurs with specific words in Arabic. To avoid repetition, the problems and the possible solutions can be summed up as follows:

- Typically, the treatment of an entry includes the use of some collocators and the omission of others, such as suggestion instead of explanation in (50).

- Given the empty space in the dictionary, we suppose that a slash between the possible, or at least the most frequent, collocators would benefit the users.

- Typically the treatment is inconsistent as to the presentation of such ex- 
pressions which are sometimes presented separately in the entry as a sub-sense or as a run-on and sometimes within the translated examples.

- A dictionary, we believe, should be consistent in the presentation of information. Constant treatment of collocations in examples alone, with many more of them, would help users.

We also noted, as explained previously in the article, the use of explicative equivalents due probably to the absence of Arabic equivalents, such as career in (57). The absence of one-word equivalents for a given English word might logically lead to the absence of collocations, but not example sentences. Entries which explain the English words rather than provide their equivalents and possible contexts of occurrence are clearly more useful for native speakers of Arabic studying English who consult the dictionary to understand a foreign word. It seems, however, that the editor expects the users to figure out how to place such potentially confusing paraphrases in Arabic sentences on their own. Such problematic entries deserve more attention and more elaboration to suit one of the dictionary's purposes: to help active speakers and writers of Arabic.

\subsubsection{Syntax items}

Following Patzold (1994: 41), we selected some items from his "syntax" list to test the dictionary in terms of its provision of grammatical combinations; in other words, to test the dictionary for such subtle and important distinctions between the different prepositions which accompany a word and how these can alter meaning. These examples illustrate the way a word's syntactic behavior often provides evidence for shifts in meaning (Atkins and Rundell 2008).

(65) Correspond to sth (66) Correspond with sb (67) Die from (68) Die of (69) Furious at (70) Furious with (71) Lecture in sth (72) Lecture on sth (73) Mad about/ for sth/sb (74) Mad at sb (75) Married to sb (76) Married with (77) Relief at (78) Relief from (79) Remember + -ing (80) Remember + to inf.

Each syntactic item calls for a different equivalent, but the only available syntax items in the OEAD are (73), (74), (79) and (80). Most verbs or adjectives in English have a number of uses associated with a particular syntactic pattern. A bilingual dictionary should definitely reflect this linguistic reality. Surprisingly, married is nonexistent in the dictionary though Arabic has an equivalent for this English word. We suggest these combinations be presented in example sentences in case presenting them separately takes up too much space from the editor's point of view.

\subsection{Other fixed expressions, metaphors, proverbs and aphorisms}

Generally speaking, learners' speech in Arabic, even at an advanced level, abounds with some unusual combinations of words which are often the result 
of literal translations of expressions from their native language. Fixed expressions, such as idioms and proverbs, reflect culture-specific concepts and are unpredictable from a semantic and a syntactic point of view. Their syntactic patterns constitute an integral part of their meanings. Any changes in word order or tense results in combinations which would not sound natural when heard by a native speaker of the foreign language. Arabic is rich in fixed expressions; on the other hand, many English expressions will not necessarily have equivalent expressions in Arabic.

Differences in figurative expressions between languages are due to the fact that languages do not lexicalize all concepts of the world, especially those which are not part of their social reality. It can be argued that using a bilingual dictionary is the most common strategy foreign learners opt for during the process of translating into the foreign language. Unfortunately, a translation dependent entirely on dictionary entries often results in wrong or unusual word combinations. We used a few expressions from Patzold's list of fixed expressions (1994: 39-40).

(81) Welcome somebody with open arms (82) Turn the clock back (83) Charity begins at home (84) Be a big fish in a small pond (85) Birds of a feather flock together (86) Turn a blind eye (87) Burn the candle at both ends (88) If you can't beat them join them (89) Play cat and mouse (90) Wipe the slate clean (91) A wolf in sheep's clothing (92) Curiosity killed the cat (93) Over my dead body (94) Fall on deaf ears (95) Lie down on the job (96) A drowning man will clutch at a straw (97) Come to the end of the road (98) Can't see further than the end of your nose (99) Give somebody a hard time (100) Have a short memory (101) On second thought (102) How dare you? (103) How should I know? (104) How do you do? (105) You're welcome (in response to 'thank you')

The expressions we could find in the OEAD are (85), (86), (87), (90), (91), (103), (104) and (105), i.e., only eight out of twenty five are available. It should be pointed out that the dictionary does contain other expressions (not listed above) for which it attempts to provide the most accurate equivalent expressions.

We are tempted to argue that the absence of the other expressions is due to the fact that they can be treated with paraphrases as there are no one-to-one equivalent expressions. But if the dictionary is also intended for the decoding Arabic-speaking users, as the editor claims, a paraphrase can be helpful. Arab users might even be able to provide precise equivalents on the basis of the paraphrases the dictionary offers. As for encoding users, a corpus might, as explained earlier in the article, be the only way to find more recent equivalent expressions. We also evaluated the above expressions in terms of their location in the entries. As some are listed under the first word and others are listed under words other than the first, we were not able to make generalizations. Much space in the OEAD is white space, so it is quite possible to include more of these expressions. 


\subsection{Usage labels}

We were curious to know whether the dictionary sets out to label items according to their stylistic level. The following list, with a few modifications, was originally proposed by Patzold (1987: 174) who selected the following informal items (bitch has been added to the list):

(106) To smash up (107) get somebody's dander up (108) dilly-dally (109) dish out (110) a drag (111) to bum a lift (112) to dodge responsibility (113) bitch

The existence of such terms would indicate that the dictionary can help users express themselves correctly in Arabic by providing equivalents which belong to the same register. The labels for informal terms in dictionaries generally vary from 'rude' or 'slang' through 'offensive' to 'taboo'. Such labels usually indicate that the use of the term will cause offence and should normally be avoided. It is particularly useful for language learners to be warned that an item is offensive or at least informal. The OEAD indicates that (108) is colloquial and is assigned the label (coll.). Bum but not bum a lift is considered vulgar (vulg.) in the OEAD. To understand this policy better, we looked up bitch (noun) and there was another label attached to the word: (derog.) for derogatory in addition to a sense discriminator (immoral or malicious woman). We did not find the verb bitch meaning to complain. The other items, however, are not labeled for their informality and (107) is missing. We also noted that a word such as crumple is labeled colloquial, though this is not the case in any of the monolingual dictionaries we consulted. We conclude with a quote by Patzold (1991: 2967) on English-German/German-English dictionaries which perfectly applies to the current situation of the English-Arabic dictionaries: "[lexicographers] should become more aware of users' needs, especially in language production. Above all, glosses, exact and plentiful labelling, and the provision of (examples in) context give users the help they need to speak and write correct and appropriate English."

\section{Conclusion}

It is clear by now that decoding and encoding users of bilingual dictionaries need different kinds of help which a single dictionary cannot provide. As Holes (1992: 163) put it: "What for one user is vital contextual exemplification and explanation might be superfluous for the other user." A bilingual dictionary for English-speaking users would enable them to distinguish and pick up the most appropriate equivalents with greater confidence. As for the OEAD, English and Arabic speakers can certainly not make equally good use of the dictionary. The dictionary needs remediation at various points before it can become a useful tool for English speakers who consult the dictionary for encoding purposes. To provide more help for this category of users, the present entries need more elaboration. By elaboration, we mean more sense discriminations should be 
made between the suggested equivalents. The use of paraphrases, which are rather explanatory, instead of 'real' equivalents which can fit in sentences can mislead anyone who is seeking le mot juste for productive use. Such explanatory phrases (potentially useful for Arab users who are decoding) should be omitted from a dictionary designed to help users in production. In order to save space, and still have a readable page layout, examples may be used to exemplify collocational, idiomatic and stylistic differences instead of presenting them in separate entries. Some 'weird' equivalents should be suppressed as they are not in common use in Arabic. The creation of a corpus would be very useful in updating the dictionary. It is also obvious from the survey based on Patzold's work that dozens of common idiomatic expressions have to be added. Encoding users need a dictionary with a more elaborate and consistent microstructure.

We also suggest that the bilingual dictionary should include other important labels such as (written) and (spoken). There are words which are more appropriate in written Arabic and never, or rarely, used in the spoken form. A modern dictionary intended to help users express themselves correctly in the foreign language should not just be representative of words that are attested in literary usage and omit everyday usages. This practice suggests a prescriptive attitude which does not reflect how Modern Standard Arabic is actually used by its speakers in the media. A descriptive approach, reflecting the actual use of contemporary Arabic, would benefit learners. The inclusion of entries without any labels indicating usage, unfortunately numerous, can lead to awkward unnatural production. The latter can also result from the addition of regional variants, with no label for national variety, which learners of Modern Standard Arabic do not really need unless their aim is to learn a particular variety of Arabic. There are many dialectal dictionaries which describe either the dialect spoken in Egypt, the Gulf, or North Africa. Including regional variants in an English-Modern Standard Arabic dictionary is a waste of space and reflects another inconsistency in the editorial policy. We believe, however, that an extensive systematic linguistic revision of the OEAD (1972) will make it more user-friendly.

A last point we should like to emphasize again at the end of the article is that the Amazon reviews deserve more of the lexicographers' attention as they can be a decisive factor in the sales of a particular English-Arabic dictionary. Some dictionaries will be left on the shelf if poorly reviewed or not reviewed at all. It is time now that editors of English-Arabic dictionaries focus their attention on the American market. It is also important to mention that despite a remarkable increase of interest in Arabic as a foreign language in the United States, users' needs, preferences, and skills surveys are virtually non-existent. As regards the interaction of users and their dictionaries, Dolezal and McCreary (1996: 133) after having gathered hundreds of publications on language learners and dictionary use still felt the need "for more empirical, quantitative, and replicable research in the field if the results are to have a wide applicabil- 
ity". When analyzing the microstructural features of English-Arabic dictionaries, their criticisms, and surveys of users' preferences, we noted that most research is directed towards Arabic-speaking users with many studies (articles and dissertations) carried out at various universities in the Arab world. AlAjmi (2002: 119) states: "Bilingual lexicography in the Arab world is suffering from a lack of guided practice and is in dire need of radical changes in both design and approach in order to keep pace with current advances, especially in EFL lexicography." We add to this that lexicographers need to concentrate their efforts on finding new techniques to gather information about the Englishspeaking users' preferences and expectations in order to meet the increasing market demands.

\section{Endnotes}

1. The 1982 COEAD claims 35000 words and phrases. Based on the 1972 OEAD, which has only 26726 entries, this seems unlikely.

2. For a list of the English-Arabic/Arabic-English dictionaries available in the library of Congress, see Selim (1992), who has compiled an exhaustive bibliography (213 pp.).

\section{References}

\section{Dictionaries}

Awde, N. and K. Smith. 2004. Arabic Practical Dictionary: Arabic-English/English-Arabic. New York: Hippocrene Books.

Baalbaki, M. 1985. Al-Mawrid Al-Wasit: English-Arabic and Arabic-English Dictionary. Beirut: Dar elIlm Lil-Malayine.

Baalbaki, M. 1997. Al-Mawrid: A Modern English-Arabic Dictionary. Beirut: Dar el-Ilm Lil-Malayine.

Baalbaki, M and R. Baalbaki. 1999. Al-Mawrid Arabic-English Dictionary. Beirut: Dar el-Ilm LilMalayine.

Baalbaki, M. and R. Baalbaki. 2001. Al-Mawrid English-Arabic and Arabic-English Dictionary. Beirut: Dar el-Ilm Lil-Malayine.

Baalbaki, M. 2002. Al-Mawrid: A Modern English-Arabic Dictionary. Beirut: Dar el-Ilm Lil-Malayine.

Baalbaki, R. 2002. Al-Mawrid: A Modern Arabic-English Dictionary. Beirut: Dar el-Ilm Lil-Malayine.

Baalbaki, M. and R. Baalbaki. 2005. Al Mawrid Al Quarib English-Arabic/Arabic-English Dictionary. Beirut: Dar el-Ilm Lil-Malayine.

Baalbaki, M. and R. Baalbaki. 2006. Al Mawrid Al Quarib English-Arabic/Arabic-English Dictionary. Beirut: Dar el-Ilm Lil-Malayine.

Cowan, J.M. (Ed.). 1994. The Dictionary of Modern Written Arabic: Arabic-English Dictionary. Wiesbaden: Otto Harrasowitz.

Doniach, N.S. 1972. Oxford English-Arabic Dictionary of Current Usage. Oxford: Oxford University Press.

Doniach, N.S. 1982. Concise Oxford English-Arabic Dictionary of Current Usage. Oxford: Oxford University Press. 
Gaafar, M. and J. Wightwick. 2004. Arabic Compact Dictionary: Arabic-English/English-Arabic. New York: Hippocrene Books.

Karmi, H.S. 1971. Al-Manar English-Arabic Dictionary. New York: St. Martin's Press.

Wehr, H. 1980. A Dictionary of Modern Written Arabic. Wiesbaden: Otto Harrasowitz.

Wortabet, J. and H. Porter. 1995. Hippocrene Standard Dictionary Arabic-English/English-Arabic. New York: Hippocrene Books.

\section{Other references}

Abu-Ssaydeh, Abdul-Fattah. 2008. Collocation and the Arabic-English Dictionary: Ideas for Better Dictionaries. Zeitschrift für Arabische Linguistik/Journal of Arabic Linguistics 48: 10-34.

Al-Ajmi, H. 2002. Which Microstructural Features of Bilingual Dictionaries Affect Users' Look-Up Performance? International Journal of Lexicography 15(2): 119-131.

Al-Kasimi, A.M. 1977. Linguistics and Bilingual Dictionaries. Leyden: E.J. Brill.

Asfour, M. 2003. Problems in Modern English-Arabic Lexicography. Zeitschrift für Arabische Linguistik/Journal of Arabic Linguistics 42: 41-52.

Atkins, B.T.S. and M. Rundell. 2008. The Oxford Guide to Practical Lexicography. Oxford: Oxford University Press.

Creamer, T. 1987. Beyond the Definition: Some Problems with Examples in Recent Chinese-English and English-Chinese Bilingual Dictionaries. Cowie, A.P. (Ed.). 1987. The Dictionary and the Language Learner: 238-245. Tübingen: Niemeyer.

Dolezal, F. and D.R. McCreary. 1996. Language Learners and Dictionary Users: Commentary and an Annotated Bibliography. Lexicographica: International Annual for Lexicography 12: 125-165.

Haas, M.R. 1962. What Belongs to a Bilingual Dictionary? International Journal of American Linguistics 28(2): 45-50.

Harrell, R.S. 1962. Some Notes on Bilingual Lexicography. International Journal of American Linguistics 28(2): 51-61.

Hausmann, F.J. et al. (Eds.). 1991. Wörterbücher. Ein internationales Handbuch zur Lexikographie/Dictionaries. An International Encyclopedia of Lexicography/Dictionnaires. Encyclopédie internationale de lexicographie. Handbücher zur Sprach- und Kommunikationswissenschaft 3. Berlin/New York: Walter de Gruyter.

Haywood, J.A. 1991. Bilingual Lexicography with Arabic. Hausmann, F.J. et al. (Eds.). 1991: 30863096.

Holes, C. 1992. Designing English-Arabic Dictionaries. De Beaugrande, R. et al. (Eds.). Language, Discourse, Translation in the West and Middle East: 161-180. Amsterdam: John Benjamins.

McCreary, D.R. 2002. Sanseido's Concise English-Japanese Dictionary. Thirteenth Edition. International Journal of Lexicography 15(4): 337-342.

Patzold, K.-M. 1987. Context is All: The BBI Combinatory Dictionary of English and the German Learner. Fremdsprachen Lehren und Lernen 16: 151-182.

Patzold, K.-M. 1991. Bilingual Lexicography: English-German, German-English. Hausmann, F.J. et al. (Eds.). 1991: 2961-2969.

Patzold, K.-M. 1994. Words, Words, Words: The Latest Crop of Dictionaries for Learners of English (Part I). Fremdsprachen Lehren und Lernen 23: 13-64. 
Selim, G.D. 1992. Arabic-English and English-Arabic Dictionaries in the Library of Congress. Washington: Library of Congress.

Shehdeh, F. and M. Bin Moussa. 2007. Practicality and Usefulness of English-Arabic Dictionaries in Translating English Metaphors. Babel 53(1): 32-47.

Schulz, E. 2004. A Student Grammar of Modern Standard Arabic. Cambridge: Cambridge University Press.

Steiner, R. 1984. Guidelines for Reviewers of Bilingual Dictionaries. Dictionaries. Journal of the Dictionary Society of North America 6: 166-180.

Welles, E.B. 2004. Foreign Language Enrollments in United States Institutions of Higher Education, Fall 2002. ADFL Bulletin 35(2-3): 7-26.

Zgusta, L. 1984. Translational Equivalence in the Bilingual Dictionary. Hartmann, R.R.K. (Ed.). 1984. LEXeter ' 83 Proceedings. Papers from the International Conference on Lexicography at Exeter, 9-12 September 1983: 147-154. Lexicographica. Series Maior 1. Tübingen: Max Niemeyer.

\section{Websites}

The Amazon website (http://www.amazon.com/) has reviews for potential buyers of any book to read. Customers are encouraged to write reviews.

The Barnes and Noble website (http: //www.barnesandnoble.com/) has a few reviews of EnglishArabic dictionaries, ususally limited to one or two per dictionary. This website also encourages customers to write reviews. Other websites for booksellers have reviews of books, but we did not find reviews of Arabic dictionaries in them. 